\title{
In Vitro Digestibility among Accessions of Big Sagebrush by Wild Mule Deer and Its Relationship to Monoterpenoid Content
}

\author{
BRUCE L. WELCH AND JORDAN C. PEDERSON
}

\begin{abstract}
Results of in vitro digestibility trials indicate that big sagebrush (Artemisia tridentata) is a highly digestible browse for wintering mule deer. Subspecies tridentata (62.1\% digested dry matter) was more highly digested than subspecies vaseyana (53.2\% digested dry matter) and subspecies wyomingensis (51.4\% digested dry matter). On an accession level, some accessions of big sagebrush were more highly digested than others. The accessional range was from $44.6 \%$ digested dry matter to $64.8 \%$. No relationship was found between total monoterpenoids (essential or volatile oils) content and digestibility.
\end{abstract}

Some accessions of big sagebrush (Artemisia tridentata) have been found to contain significantly higher levels of monoterpenoids (essential or volatile oils) than others (Welch and McArthur 1979, Welch and McArthur 1981). Our interest in the monoterpenoid content stems from the reports of Nagy et al. (1964), Oh et al. (1968), and Longhurst et al. (1969) that in high enough concentrations, these compounds may adversely affect deer digestion. If

\footnotetext{
Authors are research plant physiologist, Intermountain Forest and Range Experiment Station, Shrub Sciences Laboratory, Provo, Utah 84601; and regional game manager, Utah State Division of Wildlife Resources, Springville, Utah 84663.

The authors extend thanks to Neil H. Bingham, Jim Ekins, Dalc L. Gurley, Paul L. Tervort, Harold Blackburn, and S. Dick Worthen for their technical assistance. Also, thanks are given to Dr. E. Durant McArthur, Dr. David L. Nelson, Dr. Jerron T.

Flinders, Grant Jense, and Rodney T. John for reviewing the manuscript.

Manuscript received March 31, 1980.
}

monoterpenoids of big sagebrush do suppress digestion, we could design breeding and selection schemes aimed at developing strains of big sagebrush low in monoterpenoids. Welch and McArthur (1979) questioned the hypothesis that monoterpenoids cause digestive problems. Our main concern is that it requires a lot of time and effort to select for or against a given characteristic such as low monoterpenoids when in fact they may not be adversely affecting digestion. Therefore, we undertook this study to determine the relation between accessions of big sagebrush with varying a mounts of total monoterpenoids and their in vitro digestibility. Other non-monoterpenoid producing browse species were included in the study for comparison.

\section{Materials and Methods}

From a uniform shrub garden at the Snow Field Station ${ }^{1}$ at Ephraim, Utah, nine accessions of Artemisia tridentata (big sagebrush) were selected to study in vitro digcstibility using wild mulc deer rumen inoculum. These nine accessions contained different levels of total monoterpenoids (Welch and McArthur 1981). All three subspecies of $A$. tridentata were equally represented (three accessions each). Subspecies were identified by morphological (Beetle and Young 1965, Winward and Tisdale 1977, Mc^rthur et

1The Snow Field Station is cooperatively maintained by the Agricultural Exporiment Station of Utah State University. Snow College, Utah State Division of Wildlife Resources (W-82-R), and the Intermountain Forest and Range Experiment Station. 
al. 1979), and chemical criteria (Stevens and McArthur 1974). Within each accession, five plants were selected at random. Vegetative sa mples of current-year growth were collected at random over the entire crown of each plant. The tissue collected would represent the portion most commonly consumed by wintering mule deer, that is the first-two terminal inches of the stems with leaves. Collections were made on January 18, 1978. Samples collected from a given plant were placed in a paper bag and frozen on-site with dry ice. All samples were collected within a 90-minute period (1000-1130) to avoid diurnal variation in monoterpenoid concentration (Nicholas 1973). Samples were stored in an ultra-low freezer $\left(-35^{\circ} \mathrm{C}\right)$ until needed for grinding. Before grinding, the samples - stems with leaves - from the five plants of a given accession were pooled, ground together, and thoroughly mixed.

Samples were ground with a motorized steel mortar and pestle. Liquid nitrogen was poured over the tissue to aid in grinding the tissue to a fine powder.

After grinding, the samples were placed in plastic bottles fitted with airtight caps and stored in an ultra-low freezer $\left(-35^{\circ} \mathrm{C}\right)$.

Current-year growth was collected from five plants of each of the following: Cercocarpus ledifolius (curlleaf mahogany), Cercocarpus montanus (true mahogany), and Purshia tridentata (antelope bitterbrush). Also, hips were collected from five plants of Rosa eglanteria (sweetbrier rose). Samples were pooled on a species basis and ground as described for the nine accessions of big sagebrush.

We used the in vitro digestion procedure as outlined by Pearson (1970), except $1.0 \mathrm{~g}$ of fresh tissue was placed in digestion tubes. The dry matter content was determined for all plant samples digested. Inoculum was collected from four deer killed by personnel from the Utah State Division of Wildlife Resources. The four deer harvested for this study were killed on January 15, 22, 29, and February 5, 1979. Deer were taken from winter ranges dominated by big sagebrush. This was done to enhance the probability that the deer harvested had been eating big sagebrush long enough to have allowed the rumen microorganisms to adapt fully to the monoterpenoids (Nagy et al. 1964, and Oh et al. 1967).

The data were expressed as percent of digestible dry matter. Percentages were transformed (arcsin) for performing analysis of variance and Hardley's range test. Completely random analysis of variance was used to detect significant differences in digestibility among subspecies of big sagebrush, among nine accessions of big sagebrush, and for all species of browse studied (sagebush, bittersagebrush) and four other species of browse (hips of sweetbrier rose', curlleaf mahogany ${ }^{2}$, true mahogany ${ }^{3}$, and bitterbrush ${ }^{4}$ ). Data expressed as percent digestible dry matter.

\begin{tabular}{|c|c|c|c|c|c|}
\hline \multirow{2}{*}{$\begin{array}{l}\text { Big sagebrush } \\
\text { accession or other } \\
\text { browse species }\end{array}$} & \multicolumn{5}{|c|}{ Date of digestion trials } \\
\hline & $1 / 15 / 79$ & $1 / 22 / 79$ & $1 / 29 / 79$ & $2 / 5 / 79$ & Average \\
\hline Clear Creek $(t)^{5}$ & 69.9 & 59.8 & 59.5 & 70.0 & 64.8 \\
\hline Dove Creek (t) & 67.9 & 62.0 & 61.2 & 67.1 & 64.6 \\
\hline Loa $(t)$ & 61.1 & 55.5 & 55.0 & 56.3 & 57.0 \\
\hline Indian Peaks (v) & 63.3 & 51.8 & 55.2 & 52.7 & 55.8 \\
\hline Benmore (v) & 64.7 & 53.0 & 53.6 & 49.4 & 55.2 \\
\hline Kaibab (w) & 56.3 & 53.7 & 55.5 & 54.1 & 54.9 \\
\hline Milford (w) & 58.9 & 50.5 & 58.6 & 50.4 & 54.6 \\
\hline Sardine (v) & 53.5 & 48.6 & 49.0 & 43.8 & 48.7 \\
\hline Trough Springs (w) & 47.1 & 40.5 & 45.0 & 45.6 & 44.6 \\
\hline Rose hips ${ }^{1}$ & 56.3 & 52.2 & 40.1 & 47.6 & 49.1 \\
\hline Curlleaf ${ }^{2}$ & 49.5 & 41.3 & 45.8 & 42.0 & 44.7 \\
\hline Mahogany ${ }^{3}$ & 26.2 & 18.2 & 16.2 & 18.8 & 20.0 \\
\hline Bitterbrush ${ }^{4}$ & 24.7 & 14.3 & 21.5 & 18.7 & 19.8 \\
\hline
\end{tabular}

'Rosa eglanteria.

${ }^{2}$ Cercocarpus ledifolius.

${ }^{3}$ Cercocarpus montanus.

"Purshia tridentata.

$s_{\mathrm{t}}=$ Artemisia tridentata $\mathrm{ssp}$ tridentata

$\mathrm{v}=A$. tridentata $\operatorname{ssp}$ vaseyana

$\mathrm{w}=A$. tridentata $\mathrm{ssp}$ wyomingensis

brush, rose hips, curlleaf, and true mahogany). For significant $F$ ratios, Hardley's range test was used to compare treatment means (Snedecor and Cochran 1967).

The monoterpenoid content for each accession of big sagebrush was determined by using the methods outlined by Welch and McArthur (1981). Correlation analysis and stepwise multiple regression analysis were used to relate monoterpenoid content of nine accessions of big sagebrush to in vitro digestibility (Steel and Torrie 1960). Also, the crude protein content for each accession of big sagebrush was determined by the Kjeldahl method (Association of Official Agricultural Chemists 1965). As with monoterpenoid content, crude protein content was related to in vitro digestibility by correlation analysis and stepwise multiple regression analysis (Steel and Torrie 1960).

We wanted to know what was happening to the monoterpenoids during the digestibility trials. Therefore, we modified the digestibil-

Table 2. Comparisons (Hardley's range test) of the in vitro dry matter digestibility among three plant groupings.

Plant grouping

\begin{tabular}{|c|c|c|c|c|c|}
\hline \multicolumn{6}{|c|}{ Plant grouping } \\
\hline \multicolumn{2}{|c|}{ Subspecies of big sage brusht } & \multicolumn{2}{|c|}{ big sagebrush } & \multicolumn{2}{|c|}{$\begin{array}{l}9 \text { accessions of big sagebrush and } 4 \text { other } \\
\text { browse species }{ }^{2}\end{array}$} \\
\hline Subspecies & $\begin{array}{l}\% \text { digested } \\
\text { dry matter }\end{array}$ & Accessions & $\begin{array}{l}\% \text { digested } \\
\text { dry matter }\end{array}$ & $\begin{array}{l}\text { Accession } \\
\text { or species }\end{array}$ & $\begin{array}{l}\% \text { digested } \\
\text { dry matter }\end{array}$ \\
\hline $\begin{array}{l}\text { tridentata } \\
\text { vaseyana } \\
\text { wyomingensis }\end{array}$ & $\begin{array}{l}62.1 \mathrm{a}^{3} \\
53.2 \mathrm{~b} \\
51.4 \mathrm{~b}\end{array}$ & $\begin{array}{l}\text { Clear Creek } \\
\text { Dove Creek } \\
\text { Loa } \\
\text { Indian Peaks } \\
\text { Benmore } \\
\text { Kaibab } \\
\text { Milford } \\
\text { Sardine } \\
\text { Trough Springs }\end{array}$ & $\begin{array}{l}64.8 \mathrm{a}^{3} \\
64.6 \mathrm{a} \\
57.0 \mathrm{~b} \\
55.8 \mathrm{~b} \\
55.2 \mathrm{~b} \\
54.9 \mathrm{~b} \\
54.6 \mathrm{~b} \\
48.7 \mathrm{bc} \\
44.6 \mathrm{c}\end{array}$ & $\begin{array}{l}\text { Clear Creek } \\
\text { Dove Creek } \\
\text { Loa } \\
\text { Indian Peaks } \\
\text { Benmore } \\
\text { Kaibab } \\
\text { Milford } \\
\text { Rose hips } \\
\text { Sardine } \\
\text { Curlleaf } \\
\text { Trough Springs } \\
\text { Mahogany } \\
\text { Bitterbrush }\end{array}$ & $\begin{array}{l}64.8 \mathrm{a}^{3} \\
64.6 \mathrm{a} \\
57.0 \mathrm{~b} \\
55.8 \mathrm{~b} \\
55.2 \mathrm{~b} \\
54.9 \mathrm{~b} \\
54.6 \mathrm{~b} \\
49.1 \mathrm{bc} \\
48.7 \mathrm{bc} \\
44.7 \mathrm{c} \\
44.6 \mathrm{c} \\
20.0 \mathrm{~d} \\
19.8 \mathrm{~d}\end{array}$ \\
\hline
\end{tabular}

\footnotetext{
'Artemisia tridentata.
}

${ }^{2}$ Rose hips-sweetbrier-Rosa eglanteria

Curlleaf-curlleaf mahogany-Cercocarpus ledifolius

Mahogany-true mahogany-Cercocarpus montanus

Bitterbrush-antelope bitterbrush-Purshia tridentata.

${ }^{3}$ Values sharing the same letter superscript are not significantly different at the $5 \%$ level. 
ity trials by adding three digestive tubes that contained only buffer. To these tubes, we added specific amounts of $\alpha$-pinene and dcamphor $-2.5 \mathrm{ug} / \mathrm{ul}$. These tubes were incubated and treated like other tubes except they did not contain plant tissue or rumen inoculum. They also did not receive the acid-pepsin, and sodium carbonate treatments. After the first incubation period, we extracted the solution with absolute ether and used gas chromatography to detect any changes in the monoterpenoid content.

\section{Results}

The raw data of the four in vitro digestibility trials are given in Table 1. Significant $F$ ratios were detected (Table 2) for the following effects: subspecies of big sagebrush, accessions of big sagebrush, and for all browse species studied. Subspecies tridentata (62.1\% digested dry matter) was more highly digested by in vitro means than subspecies vaseyana ( $53.2 \%$ digested dry matter) and subspecies wyomingensis ( $51.4 \%$ digested dry matter). Clear Creek Canyon (64.8\% digested dry matter) and Dove Creek (64.6\% digested dry matter) accessions of big sagebrush (Artemisia tridentata) were more highly digested than the other seven accessions. Rose hips (Rosa eglanteria) and curlleaf mahogany (Cercocarpus ledifolius) were the only other browse species that were as digestible as some of the accessions of big sagebrush, but were not as digestible as the Clear Creek Canyon and Dove Creek accessions (Table 2). Mahogany (Cercocarpus montanus) and bitterbrush (Purshia tridentata) were significantly the least digestible of all plants tested (Table 2).

Our findings in relating monoterpenoid content and crude protein content of the nine accessions of big sagebrush to percent digested dry matter are given in Table 3. Total monoterpenoids were not significantly related to digestibility $(r=-0.09)$. The concentrations of $\alpha$-pinene $(r=-0.56), 1.8$ cineol $(r=-0.40), \alpha-$ thujone $(r=-0.06), \beta$-thujone $(r=-0.39)$, and terpineol $(r=-0.10)$ were not significantly related to percent digested dry matter. Camphene $(r=-0.75)$ and camphor $(r=-0.75)$ were significantly related to percent digested dry matter, but not at the $1 \%$ level. The crude protein level $(r=0.80)$ was significantly related to percent digested dry matter at the $1 \%$ level.

Stepwise multiple regression analysis revealed that the content of crude protein accounted for $64 \%$ of the variation of digestible dry matter among the nine accessions of big sagebrush. An additional $25 \%$ of the variation was accounted for by adding camphor content to the regression equation. Other variables, total monoterpenoids, and individual monoterpenoids contributed only $1 \%$ or less to the regression.

We found that $100 \%$ of the $\alpha$-pinenc added to control flasks (buffer only) was lost. Loss of camphor was $17.3 \%$. All three control flasks, however, contained a white condensate ring around the neck of the flask. This condensate ringe was located about 70 $\mathrm{mm}$ above the surface of the digestion solution and was identified to be camphor.

\section{Discussion}

Our result s indicate that big sagebrush is a highly digestible food for wintering mule deer. Other workers agree with the results we have obtained (Sheehy 1975, Urness et al. 1977, and Wallmo et al. 1977). Unfortunately, as Wallmo et al. (1977) pointed out, preparatory techniques such as oven drying may result in large losses of monoterpenoids, thus introducing bias. Also, Welch and McArthur (1979) pointed out possible large losses of monoterpenoids due to freeze drying. We ran a test to determine the loss of monoterpenoids due to oven drying and freeze drying. We found that oven drying at $100^{\circ} \mathrm{C}$ caused a total loss of monoterpenoids. Freeze drying caused a $78 \%$ loss. We were able to overcome these preparatory techniques by grinding the big sagebrush tissue (fresh), submerged in liquid nitrogen, with a motorized steel mortar and pestle.

We found very little relationship between digestibility and total monoterpenoid content. Connolly et al. (1980) found similar results using Douglas-fir and deer rumen inocula. On an individual monoterpenoid basis, camphene and camphor had a significant negative effect on digestion. We are unable to explain the significant negative effect camphene and camphor appear to have on digestibility among the nine accessions of sageb rush. Milford, Loa, and Clear Creek accessions contained about the same amount of camphor, but Clear Creek was significantly more digestible than the Milford and Loa accessions. This is also true for camphene. Trough Springs, Sardine Canyon, and Kaibab accessions contained the same amount of camphene but Kaibab was significantly more digestible than the Trough Springs. Our reluctance to accept the statistically significant effects of camphene and camphor on digestions stems from two points: First, we selected the accessions purposely for varying amounts of total monoterpenoids not for individual monoterpenoids-our test for individual monoterpenoids may not be valid; and secondly, in vitro digestibility values for big sagebrush are among the highest recorded for shrubs (Welch and McArthur 1979). In the multiple regression equation, camphor content accounted for about $25 \%$ of the digestibility variation among the accessions, whereas, camphene accounted for less than $1 \%$. From a biological point, the impact of these two monoterpenoids must be small. If not, the high percentage of digested matter would not have been obtained. Crude protein levels had a significant positive relation to digestibility.

This lack of a relationship between digestibility and total monoterpenoid content and the high percentage of digested dry matter contrasted with the findings or statements of Nagy et al. (1964),

Table 3. The relationship between percent digestible dry matter (in vitro) and total monoterpenoids (essential oils), individual monoterpenoids, and crude protein of nine accessions of big sagebrush. ${ }^{1}$

\begin{tabular}{|c|c|c|c|c|c|c|c|c|c|c|}
\hline Accession & $\begin{array}{l}\% \text { digested } \\
\text { dry matter }\end{array}$ & $\begin{array}{l}\text { Total } \\
\text { monoter- } \\
\text { penoids }\end{array}$ & $\alpha$-Pincne & Camphene & 1,8 Cineol & $\alpha$-Thujone & $\beta$-Thujone & Camphor & Terpineol & $\begin{array}{l}\text { Crude } \\
\text { protein }\end{array}$ \\
\hline Trough Springs & 44.6 & $1.41^{2}$ & .09 & .09 & .08 & .00 & .00 & .89 & .02 & 11.0 \\
\hline Sardine & 48.7 & 1.74 & .02 & .11 & .06 & .25 & .58 & .62 & .05 & 10.5 \\
\hline Milford & 54.6 & .99 & .05 & .03 & .01 & .13 & .04 & .22 & 0 & 11.2 \\
\hline Kaibab & 54.9 & .93 & .11 & .11 & .02 & .00 & .00 & .63 & .01 & 11.9 \\
\hline Benmore & 55.2 & 2.89 & .00 & .00 & .09 & .96 & .49 & .05 & .32 & 10.0 \\
\hline Indian Peaks & 55.8 & 1.72 & .00 & .04 & .12 & .03 & .02 & .31 & .01 & 11.2 \\
\hline Loa & 57.0 & 1.91 & .01 & .03 & .09 & .13 & .55 & .28 & .05 & 14.5 \\
\hline Dove Creek & 64.6 & 1.70 & .00 & .00 & .02 & .07 & .71 & .13 & 0 & 16.0 \\
\hline Clear Creek & 64.8 & .95 & .00 & .00 & .02 & .05 & .31 & .24 & .01 & 15.3 \\
\hline$r$ & - & -.09 & -.56 & -.75 & -.40 & -.06 & -.39 & -.75 & -.10 & .80 \\
\hline$r^{2}$ & - & .008 & .31 & .56 & .16 & .003 & .15 & .56 & .01 & .64 \\
\hline
\end{tabular}

${ }^{1}$ Artemisia tridentata.

${ }^{2}$ Data for monoterpenoids expressed on a percent dry matter basis. 
Nagy and Tengerdy (1968), Oh et al. (1968), Dietz and Nagy (1976), Wallmo et al. (1977), Nagy and Regelin (1977), Carpenter et al. (1979). In general, these workers have shown that at certain levels, monoterpenoids suppressed the in vitro growth of rumen microorganisms, rate of cellulose digestion, and the rate of gas and volatile fatty acids production of deer rumen microorganisms. Estimates of the amount of big sagebrush that deer can consume before the monoterpenoids start to interfere with digestion varies from 15 to $50 \%$ of the diet (Nagy et al. 1964, Nagy and Tengerdy 1968, Dietz and Nagy 1976, Wallmo et al. 1977).

Although we do not question the results of these in vitro studies or estimates of the amount of big sagebrush that can be safely eaten, we do question whether the suggested suppression by monoterpenoids occurs under range conditions. First, in vivo digestion trials conducted by Smith (1950), Bissell et al. (1955), and Dietz et al. (1962) determined the total digestible nutrients (TDN) content of big sagebrush to be $70.2 \%, 55.9 \%$, and $58.9 \%$, respectively. Nagy 1979 citing the protein digestion coefficients from these studies concluded that big sagebrush digestibility is poor to fairly poor. We cannot understand how a roughage with a reported mean TDN content of about $59 \%$ can be considered poor to fairly poor in digestibility (see review by Welch and McArthur 1979). High quality alfalfa has a TDN content of about 53\% (Morrison 1961, National Academy of Sciences 1964). Secondly, we propose that the monoterpenoids are lost from the rumen and therefore do not interact significantly with the rumen microorganisms. This hypothesis is based on our observations that $\alpha$-pinene was lost from the in vitro digestion tubes and that camphor formed a condensated ring about $70 \mathrm{~mm}$ above the surface of the in vitro digestion solution. The force that drove these compounds (pinene and camphor) out of the digestion solution was heat. Apparently $38.5^{\circ} \mathrm{C}$, which is close to the normal body temperature of mule deer, is sufficient to volatilize the monoterpenoids (Moen 1973). We can visualize three ways in which monoterpenoid levels in the deer rumen can be greatly reduced: (1) loss through mastication and rumination, (2) heat from the body volatilizing the monoterpenoids resulting in the monoterpenoid being expelled from the rumen by eructation, and (3) possible adsorption in the rumen and excretion through the kidneys (Cook et al. 1952, Annison 1965). We will be testing this hypothesis in the ncar future. If the hypothesis is true, we will be able to explain the apparent conflict between the in vitro studies showing the monoterpenoid suppress deer rumen microorganisms and the results of our study showing that big sagebrush is a highly digestible forage for deer.

\section{Literature}

Annison, E.F. 1965. Absorption from the ruminant stomach. p. 185-197. In: Physiology of Digestion. R.W. Dougherty (ed.).

Association of Official Agricultural Chemists. 1965. Official Methods of Analysis, 10th ed. Washington, D.C.

Beetle, A.A., and A. Young. 1965. A third subspecies in the Artemisia tridentata complex. Rhodora 67:405-406.

Bissell, H.D., B. Harris, H. Strong, and F. James. 1955. The digestibility of certain natural and artifical food eaten by deer in California. California Fish and Game 41:57-78.

Carpenter, L.H., O.C. Wallmo, and R.B. Gill. 1979. Forage diversity and dietary selection by wintering mule deer. J. Range Manage. 32:226-229.

Connolly, G.E., B.O. Ellison, J.W. Fleming, S. Geng, R.E. Kepner, W.M. Longhurst, J.H. Oh, and G.F. Russell. 1980. Deer browsing of Douglasfir trees in relation to volatile terpene composition and in vitro fermentability. Forest Sci. 26:179-193.

Cook, C.W., L.A. Stoddart, and L.E. Harris. 1952. Determining the digestibility and metabolizable energy of winter plants by sheep. J. Anim. Sci. 11:578-590.

Dietz, D.R., and J.G. Nagy. 1976. Mule deer nutrition and plant utilization. p. 71-78. In: Mule Deer Decline in the West-a Symposium. G.W. Workman and J.B. Low (eds.). Coll. Nat. Resour., Utah Agric. Exp. Sta., Logan. 134 p.
Dietz, D.R., R.H. Udall, and L.E. Yeager. 1962. Chemical composition and digestibility by mule deer of selected forages species. Cache la Poudre Range, Colorado. Colorado Fish and Game Dep. Tech. Pub. $14: 76$.

Longhurst, W.M., J.H. Oh, M.B. Jones, and R.E. Kepner. 1969. Deer forage palatability, digcstibility, and management implications. Paper given: California-Nevada Section of the Wildlife Society Annu. Meet., February 1, 1969, Berkeley, Calif. 10 p.

McArthur, E.D., A.C. Blauer, A.P. Plummer, and R. Stevens. 1979. Characteristics and hybridization of important intermountain shrubs. III. Sunflower family. U.S. Dep. Agr. Forest Serv. Res. Pap. INT-220, 82 p. Intermt. Forest and Range Exp. Sta., Ogden, Utah.

Moen, A.N. 1973. Wild life Ecology: an Analytical Approach. W.H. Freeman and Co., San Francisco, Calif. $458 \mathrm{p}$

Morrison, F.B. 1961. Feeds and Feeding, Abridged 9th Ed. The Morrison Publishing Co., Clinton, Iowa.

Nagy, J.G. 1979. Wildlife nutrition and the sagebrush ecosystem. p. 164168. In: Sagebrush Ecosystem Symposium. G.F. Gifford, F.E. Busby, and J.P. Shaw (eds.). Coll. of Natur. Resour. Utah Agr. Exp. Sta., Logan.

Nagy, J.G., and W.L. Regelin. 1977. Influence of plant volatile oils on food selection by animals. 13th Congress of Game Biologists, 13:225-230.

Nagy, J.G., and R.P. Tengerdy. 1968. Antibacterial action of essential oils of Artemisia as an ecological factor. II. Antibacterial action of the volatile oils of Artemisia tridentata (big sagebrush) on bacteria from the rumen of mule deer. Appl. Microbiol. 16:441-444.

Nagy, J.G., H.W. Steinhoff, and G.M. Ward. 1964. Effects of essential oils of sagebrush on deer rumen microbial function. J. Wildl. Manage. 28:785-790.

National Academy of Sciences. 1964. Nutrient requirement of domestic animals. No. 5. Nutrient requirement of sheep. A report of the Committee on Animal Nutrition. Nat. Res. Counc. Pub. 1193:31-34. Washington, D.C

Nicholas, H.J. 1973. Terpenes. p. 254-309. In: Organic MetabolitesPhytochemistry Vol. II. L.P. Miller (ed.), Van Nostrand Reinhold Co., New York.

Oh, H.K., T. Sakai, M.B. Jones, and W.M. Longhurst. 1967. Effects of various essential oils isolated from Douglas-fir needles upon sheep and deer rumen microbial activity. Appl. Microbiol. 15:777-784.

Oh, H.K., M.B. Jones, and W.M. Longhurst. 1968. Comparison of rumen microbial inhibition resulting from various essential oils isolated from relatively unpalatable plant species. Appl. Microbiol. 16:39-44.

Pearson, H.A. 1970. Digestibility trials: In vitro techniques. p. 85-92. In: Range and wildlife habitat evaluation-a research symposium. H.A. Paulson, Jr., E.H. Reid, and K.W. Parker (eds.). U.S. Dep. Agr. Forest Serv. Misc. Pub. No. 1147.

Sheehy, D.P. 1975. Relative palatability of seven Artemisia taxa to mule deer and sheep. M.S. Thesis, Oregon State Univ., Corvallis, 147 p.

Smith, A.D. 1950. Sagebrush as winter food for mulc decr. J. Wildl. Manage. 14:285-289.

Snedecor, G.W., and W.G. Cochran. 1967. Statistical Methods. Iowa State Univ. Press, Ames. 593 p.

Steel, R.G.D., and J.H. Torrie. 1960. Principles and Procedures of Statistics. McGraw-Hill Book Co., New York. 481 p.

Stevens, R., and E.D. McArthur. 1974. A simple field technique for identification of some sagebrush taxa. J. Range Manage. 27:325-326.

Urness, P.J., A.D. Smith, and R.K. Watkins. 1977. Comparison of in vivo and in vitro dry matter digestibility of mule deer forages. J. Range Manage. 30:119-121.

Waïlmo, O.C., L.H. Carpenter, W.L. Regelin, R.B. Gill, and D.L. Baker. 1977. Evaluation of deer habitat on a nutritional basis. J. Range Manage. $30: 122-127$

Welch, B.L., and E.D. McArthur. 1979. Feasibility of improving big sagebrush (Artemisia tridentata) for use on mule deer winter ranges. $p$. 415-473. In: Proceedings of the International Arid Lands Conference on Plant Resources. J.R. Goodin and D.K. Northington (eds.). Texas Tech. Univ., Lubbock.

Welch, B.L., and E.D. McArthur. 1981. Variation of monoterpenoid content among subspecies and accessions of Artemisia tridentata grown in a uniform garden. J. Range Manage. 34:380-384.

Winward, A.H., and E.W. Tisdale. 1977. Taxonomy of the Artemisia tridentata complex in Idaho. Coll. Forest Wildl., and Range Sci., Univ. of Idaho, Moscow. Bull. 19, 15 p. 